American Journal of Agricultural and Biological Sciences 5 (2): 228-234, 2010

ISSN 1557-4989

(C) 2010 Science Publications

\title{
Regression Analysis of Effective Factor on People Participation in Protecting, Revitalizing, Developing and Using Renewable Natural Resources in Ilam Province from the View of Users
}

\author{
${ }^{1}$ Bagher Arayesh and ${ }^{2}$ Sayed Jamal Hosseini \\ ${ }^{1}$ Department of Agricultural, Islamic Azad University, Ilam Branch, Iran \\ ${ }^{2}$ Department of Agricultural, Islamic Azad University, Science and Research Branch, Iran
}

\begin{abstract}
Problem statement: The purpose of this study was the regression analysis of effective factor on people participation in protecting, revitalizing, developing and using renewable natural resources in Ilam province. Approach: This study was a casual comparative and applies one. Sample was taken from natural resources users. Results: The sample size of groups was 317 for users respectively. For sample selection, stratified, cluster and multiple sampling were utilized. The main tools for gathering data were questionnaire. The reliability and validity of the questionnaire were obtained by experts and pilot study and its Alfa level was 88\%. Descriptive and inferential statistics were used and data was analyzed by sp. 15. To test the hypothesis, correlation, multiple regressions were employed. Conclusion: The result indicated that level of education, rate of media using, users trusting on natural resources executive, consulting with users before implementation the plans, number of cattle's, kind of occupation, users membership in public institution and organization, social status of users, Technical knowledge of users, present status of natural of natural resources extensive plans, political and low full support of users, amount of loan received by users and organizing nature assistant, have a significant role on people participation on protecting, revitalizing, developing and using renewable natural resources.
\end{abstract}

Key words: Participation people, natural resources, extension, public organization

\section{INTRODUCTION}

Natural resources of every society are the wealth of that society which not only belongs to the present generation, but also a heritage belongs to posterity. But we must admit that the role of natural resources have never been so vital and useful for human beings at no moment in history and their existence have never been threatened by human in such a broad scale (Shariaati and Reza, 2004). These warns will be more serious when 1.5 million hectares of agricultural, forestry lands and pastures turn to dessert in our country annually. Whereas, around 200 tones of soil go to seas, lakes and to the dams in every moment. In fact, around 20 tones of soil is constantly washed by erosion in Iran every year and this means losing of $76 \mathrm{~kg}$ Azotes, $24 \mathrm{~kg}$ phosphorus, $8 \mathrm{~kg}$ potash in each hectares. If we add the value of food in soil, we will lose about 7.6 million dollars of micro-nutritious available in soil yearly. Ilam province is one of the situated provinces in the west of Iran, located on the path of vegetative zone of Zagros. This province has entirely $11 \%$ of the Zagros forests, $4 \%$ forests of Iran, 4.97of whole vegetative pastures of
Zagros and $8 \%$ of whole pastures of Iran. On the other hand, $87.38 \%$ of this province is the base of natural resources (The Forests and Pastures Organization, 2007). Besides, with considering the current rate of natural resources in Iran and it's provinces and the problem concerned to it which are directed to the present and future generation, there is absolutely no way to compare the rate of destruction with the measures done to protect, revival, using of natural resources. To overcome such problems, the role of government as planner and protector of the projects related to natural resources is obvious and important. But this is completely evident that the accomplishment of these projects needs people participation. The main issue is that the people of this province don't associate in protecting, revival, development and using projects. Their attitude toward natural resources is more based on wrong using and use of these resources. Furthermore, it seems that the attitude of rural and tribal society toward the projects presented by government is not positive and these projects are not granted for cultural and historical aspects. In the way that in projects like the balance of livestock and pastures, guide project, the

Corresponding Author: Bagher Arayesh, Department of Agricultural, Islamic Azad University, Ilam Branch, Iran 
project of preserving of natural resources, the Green Movement, the participation of people, in spite of the spending huge costs by government, had the minimum rate among the other provinces which are situated in vegetative zone of Zagros (The Forests and Pastures Organization, 2007). We can look for the consequences of having not participation of people dealing with the processes like protecting, revival, development and using of natural resources in increasing the rate of destruction of these resources which has the scale of 1.3 times more than other provinces in Zagros zone and also in increasing of pasturage capacity on the scale 5.3 times more than pastures and increasing of exploiters emigration to cities (The Forests and Pastures Organization, 2007). The past experience show that the preventing natural resources from destruction and using of stable management to these resources, because of the broadness of resources and limitation of governmental resources is beyond the capacity of government sector).

Literature review: Paying attention to natural resources from different perspectives attracts many scientists' researchers. Every researcher studied the effective factors on natural resources from different points Malek Mohammadi (1999); Razaki (2000); Perti (2003); Samari (2004) and Shariaati and Reza (2004) acknowledged the role of Extension-education (emphasizing on applied education) and it's effect on protecting, revival, development and using of natural resources which are renewable. Motavali (2004) and Osman (2007) believe that the personal factors such as (level of education, course of study, work place, the situation of work place, matrimonial status, the resources of earning income, the interest of the people involved, the number of family members, the kind of job, age) have influenced the processes of protecting, revival, development and using of renewable natural resources (Kaliqi et al., 2004; Hossieni et al., 2006) studied this form the economical point of view and they mentioned the influential factors such as income, the amount of irrigated and non-irrigated lands, the transportations, the number of livestock, granting banking facilities (Razaki, 2000; Fisher, 1993; Perti, 2003; Malek Mohammadi, 1999; Mirbod, 2000) acknowledged the effect of institutions and popular organizations and non-governmental organization in processes of protecting, revival, development and using of renewable natural resources. some other researchers believe that the government has effects (like obviation of limitations of people ownership, decentralization and granting affairs, enforcing people-government relationship, executing obligations on behalf of government, believing people participation, the professional capabilities of the people in charge and specialists, informing people, finding people's problems and proper policy making in protecting, revival, development and using of renewable natural resources. (Samari, 2004; Mousavi, 2001; Shariaati and Reza, 2004; Motavali, 2004; Hossieni et al., 2006; Pop Zan, 2006; Barret, 1991; Kodere, 1995), construed the social factors (like: Social class, the kind of job, education, job experience, the kind of attitude towards the project, empowering the local associations, taking into account the indigenous knowledge, considering the right of ownership, making jobs, the being and presence of local leaders) as effective factors on processes of protecting, revival, development and using of renewable natural resources. (Pop Zan, 2006; Azkya, 2001; Hossieni et al., 2006; Malek Mohamad, 1999) found psychological factors as influential factor in processes of protecting, revival, development and using of renewable natural resources. Some other researchers (Pop Zan, 2006) alluded to the physical and structural factors (strength, physical health, physical capability,) cornering the processes of protecting, revival, development and using of renewable natural resources natural. (Malek Mohammad, 1999; Shaeri, 1998; Shariaati and Reza 2004; Samari, 2004; FAO, 2000) considered the professional training of Extension agents of natural resources and people and user's participating in structural classes as effective factors in protecting, revival, development and using of renewable natural resources.

In the research which was done between the variables of educational level, the amount of information which people have about the importance and advantages of forests, participation in instructiveextension classes, using of extension magazines and periodicals, using of educational films, using of lecture meetings, using of educational programs of radio, using of TV, the number of contacts with extension agents and contacts with honorary extension agents, supplying fuel by government and the variable related to rate of people participation in protecting forests, positive and meaningful relationship has not been reported.

In this survey between the age variables, using of the programs of literacy crusade, the number of visits, the state of people awareness about the rules regarding protecting and supporting of forests and the variable of people associations, a meaningful relationship have not been reported. In this survey, the independent variable of supplying of burnable materials by government, being cognizant about the importance of contacts with honorary forest protectors and participation in 
educative-extension classes have the utmost effect on the dependent variable of people participation, respectively. in the survey which (Motavali, 2004) have done, there have not been opposite and meaningful relationship between the variables of the corporation of government organizations, supplying burnable materials foe rural people by government and the problems which appear on the way of protecting natural resources. (Kaliqi et al., 2004) have studied the variable like age, literacy, transportation facilities, family dimension (its size), livestock unit, the hectares of irrigated and non-irrigated lands and people participation.

The general purpose of this research is the regression analysis of the effective factors on people association in processes of protecting, revival, development and using of renewable natural resources from user's view of Ilam Province.

The special purposes of this study are:

- The study of personal characteristics of the users of natural resources

- 2-The study of relationship between the research variables and people participation in processes of protecting, revival, development and using of renewable natural resources natural

- Determination of the expressive factors of the variable of people participation from user's point of view

\section{MATERIALS AND METHODS}

This is an applied research. Because it is to apply the theories, rules and principle which are based on Theoretical assumption to solve the problems. It is casual-relative Research. It is impossible to control variables and Therefore It is a quasi-experimental research. The questionnaires have used to collect data. To be sure that questionnaire is valid. The advice and supervisor professor of Ilam Azad University and Tehran Azad University are used. To test the reliability of questionnaire, Thirty questionnaire had been answered and Cronbach alpha calculated $(\mathrm{a}=88 \%)$ and this number was a suitable (good) final factors in these research. The sample size was calculated using Cochran formula and it included 317 users. Stratified and cluster sampling and was used for users respectively. The spss software was used to analyze the data. To test the hypothesis, correlation, multiple regression were employed.

\section{DISCUSSION AND RESULT}

Personal characteristics: The research findings showed that $4.3 \%$ of users are below the age of 20 and $5.3 \%$ of them are above the age of 60 . On this basis, the most frequency of users was 100 persons, between 2030 year old people.74\% (232 persons) of users were married and $25.9 \%$ ( 81 persons) were single. $21.5 \%$ (68 persons) declared the number of their family member 4. (they ore four in family), whereas $0.3 \%$ ( 1 person) of users declared the number of their family members 16.the level of education of $21.9 \%$ (67persons) of users is in the level of illiterate and $8.5 \%$ (27 persons) had the B.A degree. In addition, $6.3 \%$ (20 persons) of users had just passed the high school education course. The most frequency of this classes belonged to fairly illiterate people (21.9) and the minimum frequency belonged to the people with high school education course $(6.5 \%)$. users have averagely 55 heads. $29.4 \%$ declared the number of their livestock between 20-40 heads and 34,9\% (110persons) of users (the at most frequency) declared the amount of their irrigated lands below 5 ha whereas $10.4 \%$ ( 33 persons) (the minimum frequency) declared the amount of their irrigated land 41.55 ha $24.1 \%$ ( 76 persons) of users (the utmost frequency) declared the amount of their garden land below 3 ha whereas $16.8 \%$ (the minimum frequency) declared the amount of their garden lands between 1117 ha Furthermore, the average amount of garden lands of exploiters is 10.5 ha.

\section{The findings of inferential analysis:}

Correlation studies: In order to study the relationship of research variables, we use the Spearman correlation coefficient Table 1 shows the results of this part.

The multi-variable regression analysis: At this stage, we use the multi-variable regression by means of backward method in order to evaluate the cumulative effect of independent variables on dependent variables of people participation in protecting, revival, development and using of natural resources. In this method, all independent variables come in to analysis and the effects of all independent variables on dependent variables will be tested. But, the weaker variables, one after another will gradually go out of this equations and eventually these phases will be continued till the time when the error of a meaningful test gets $10 \%$. Table 2 shows the finding of the regression analysis. 
Am. J. Agri. \& Biol. Sci., 5 (2): 228-234, 2010

Table 1: The relationship between variables under study

\begin{tabular}{|c|c|c|}
\hline First variable & $\mathrm{R}$ & $\mathrm{P}$ \\
\hline Participation in educative-extension classes & 0.020 & 0.730 \\
\hline The user's level of education & 0.100 & 0.100 \\
\hline Professional capability of executive agents & $0.480 * *$ & 0.000 \\
\hline Using of communicative media & 0.065 & 0.320 \\
\hline Amount of user's income & 0.083 & 0.270 \\
\hline Reliance of user's on executive agents & $0.198^{*}$ & 0.002 \\
\hline User's'self-confidence & 0.074 & 0.252 \\
\hline Consulting users before executing the project & 0.012 & 0.858 \\
\hline The amount of contacts of users to extension & $0.230 * *$ & 0.000 \\
\hline The amount of loan granted to users & 0.031 & 0.724 \\
\hline The status of relations between users and governmental institutions & 0.018 & 0.787 \\
\hline The type of user's real job & 0.007 & 0.919 \\
\hline The state of users participation in popular organization & $0.480 * *$ & 0.000 \\
\hline The social participation of user's & $0.460 * *$ & 0.000 \\
\hline The users social status & $0.397 * *$ & 0.000 \\
\hline The users cultural characteristics & $0.296 * *$ & 0.000 \\
\hline The awareness of users about the importance and purposes of projects & 0.081 & 0.213 \\
\hline Decentralization in extension management & 0.069 & 0.287 \\
\hline Paying attention to users interest and needs & $0.276^{* *}$ & 0.000 \\
\hline The users attitude toward participation & $0.158^{*}$ & 0.014 \\
\hline The degree of presented services too users & $0.378 * *$ & 0.000 \\
\hline The levels of technical knowledge of the users & $0.768 * *$ & 0.000 \\
\hline The current status of extension programs & $0.468 * *$ & 0.000 \\
\hline The requisite planning for participation & 0.081 & 0.210 \\
\hline The legal and political protections & $0.503^{* *}$ & 0.000 \\
\hline The amount of received facilities to users & $0.197 * *$ & 0.002 \\
\hline The amount of irrigated and non irrigated lands organizing local association & 0.430 & 0.684 \\
\hline Organizing local societies & $0.347 * *$ & 0.000 \\
\hline
\end{tabular}

**: It is meaningful on the scale of $0.10 ; *$ : It is meaningful on the scale of 0.05

Table 2: The findings of multi-variables, dependent variable (participation in protecting, revival, development and using of natural resources) regression analysis

\begin{tabular}{|c|c|c|c|c|}
\hline Dependent variables & $\mathrm{B}$ & Beta & $\mathrm{T}$ & Sig. \\
\hline Participation in educative-extension courses & 0.112 & 0.161 & 1.520 & 0.146 \\
\hline The user's level of education & 0.180 & 0.478 & 5.040 & 0.000 \\
\hline Professional capability of executive agents & 0.001 & 0.004 & 0.056 & 0.956 \\
\hline Using of communicative media & 01.000 & 0.540 & 4.740 & 0.000 \\
\hline Reliance of user's on executive agents & 0.236 & 0.311 & 4.810 & 0.000 \\
\hline User's 'self-confidence & 0.105 & 0.146 & 0.710 & 0.107 \\
\hline Consulting users before executing the project & 0.396 & 0.587 & 0.630 & 0.002 \\
\hline The amount of contacts of users to extension agents & 0.035 & 0.056 & 0.762 & 0.456 \\
\hline The amount of loan granted to users & 0.056 & 0.127 & 2.480 & 0.024 \\
\hline The status of relations between users and governmental institutions & 0.168 & 0.246 & 1.800 & 0.089 \\
\hline The type of user's real job & 0.063 & 0.167 & 3.200 & 0.005 \\
\hline The state of users participation in popular organization & 0.373 & 0.640 & 0.530 & 0.000 \\
\hline The social participation of user's & 0.026 & 0.134 & 0.837 & 0.414 \\
\hline The users social status. & 0.310 & 0.590 & 0.320 & 0.000 \\
\hline The users cultural characteristics & 0.122 & 0.577 & 6.860 & 0.000 \\
\hline The awareness of users about the importance and purposes of projects & 0.002 & 0.005 & 0.036 & 0.972 \\
\hline Decentralization in extension management & 0.153 & 0.202 & 1.480 & 0.156 \\
\hline Paying attention to users interest and needs & 0.330 & 0.508 & 5.170 & 0.000 \\
\hline The users attitude toward participation & 0.379 & 0.566 & 5.410 & 0.000 \\
\hline The degree of presented services too users & 0.001 & 0.016 & 0.246 & 0.809 \\
\hline The levels of technical knowledge of the users & 0.083 & 0.610 & 9.170 & 0.000 \\
\hline The current status of extension programs & 0.300 & 0.209 & 4.640 & 0.000 \\
\hline The requisite planning for participation & 0.003 & 0.005 & 0.061 & 0.952 \\
\hline The legal and political protections & 0.191 & 0.740 & 10.750 & 0.000 \\
\hline The amount of received facilities to users & 0.104 & 0.178 & 2.060 & 0.040 \\
\hline The amount of irrigated and non irrigated lands organizing local association & 0.074 & 0.100 & 1.450 & 0.165 \\
\hline Organizing local societies & 0.321 & 0.522 & 5.690 & 0.000 \\
\hline
\end{tabular}

$\mathrm{R}=0.841 ; \mathrm{R}^{(2)}=0.66 ;$ Standard error of $\mathrm{R}=0.48 ;$ Modified $\mathrm{R}^{(2)}=0.65$ 
The calculated determination factor $\left(\mathrm{R}^{2}=0.66\right)$ shows that the 27 available variables which 16th of them are have meaning explain $66 \%$ of the changes of dependent variable (participation in processes of protecting, revival, development and using of renewable natural resources).

This math equation shows the relation between the dependent and independent variables as follows:

$$
\begin{aligned}
\mathrm{Y}= & 0.48+01 \mathrm{X}_{4}+0.23 \mathrm{X}_{5}+0.39 \mathrm{X}_{7}+0.56 \mathrm{X}_{9}+0.063 \mathrm{X}_{11}+ \\
& 0.37 \mathrm{X}_{12}+0.31 \mathrm{X}_{14}+0.123 \mathrm{X}_{15}+0.33 \mathrm{X}_{18}+0.37 \mathrm{X}_{19}+ \\
& 0.083 \mathrm{X}_{12}+0.3 \mathrm{X}_{22}+0.19 \mathrm{X}_{24}+0.1 \mathrm{X}_{25}+0.32 \mathrm{X}_{27}
\end{aligned}
$$

In fact, the result of analyzing the variance for regression equation is meaningful $(\mathrm{P}=0.000 \mathrm{f}=70.93)$

\section{CONCLUSION}

This survey was done with the purpose of regression analysis of effective factors on people association in protecting, revival, development and using of renewable natural resources of Ilam. This studies which were done by correlation coefficient showed that there is a relationship between the variables of the professional capabilities of executive agents, reliance of users on the executives of natural resources projects, the number of contacts of users with extension agents, the rate of users participation in popular associations, the user's social participation, the social status of users, the cultural characteristics of users, paying attention to interests and needs of users, the amount of presented extension services to users, the level of technical knowledge of users, the current status of extension programs, the legal and political supports, the amount of received facilities and organizing of local associations with the participation in protecting, revival, development and using of natural resources. The Finding of regression analysis showed that the users association in extension-educative courses had no meaningful effect on people participation in activities like protecting, revival, development and using of natural resources $(\mathrm{p}=0.146, \mathrm{t}=1.52)$. The level of education of users, with 0.99 assurances, had meaningful effect on people participation in activities concerning protecting, revival, development and using of natural resources. $(\mathrm{p}=0.000, \mathrm{t}=5.04)$. The professional capabilities of executive agents had no meaningful effect on people association in activities related to protecting, revival, development and using of natural resources. $(\mathrm{p}=0.95, \mathrm{t}=56 \%)$. The rate of using of communicative media has meaningful effect on people participation in protecting, revival, development and using of natural resources $(\mathrm{p}=0.000, \mathrm{t}=4.74)$. The reliance of users on executives of natural resources projects with the scale of 0.01 , also plays a part in their participation in activities related to protecting, revival, development and using of forests and pastures. $(\mathrm{p}=$ $0.000, \mathrm{t}=4.47)$. Consulting users before executing projects, had meaningful effect on dependent variable of people participation with the scale of 0.05 . $(\mathrm{p}=$ $0.002, t=4.81)$. The self-confidence of users had no effect on dependent variable of people participation in protecting, revival, development and using of natural resources. $(\mathrm{p}=0.107, \mathrm{t}=1.70)$.

The number of contacts of users with extension agents had meaningful role and effect on the dependent variable of people participation $(\mathrm{p}=0.456, \mathrm{t}=0.762)$. The amount of livestock on the scale of 0.1 had no meaningful effect on people participation in protecting, revival, development and using of natural resources $(\mathrm{p}=0.024, \mathrm{t}=2.48)$. The state of relationship between users and governmental institutions had no effect on dependent variable of people participation in programs of protecting, revival, development and using of natural resources. $(\mathrm{p}=0.089, \mathrm{t}=1.80)$.

The kind of user's real job has a meaningful effect on dependent variable of people participation on the scale 0.01. $(0.005, \mathrm{t}=3.20)$. The membership of users in popular institutions and organizations, with the scale of 0.01 had a meaningful effect on dependent variable of participation in programs like protecting, revival, development and using of natural resources. $(p=0.000$, $t=9.53)$. The social status of users with the scale of 0.01 had a meaningful effect on dependent variable of people $(\mathrm{p}=0.000, \mathrm{t}=7.32)$. The independent variable of cultural characteristics of users, with the scale of 0.01 had meaningful effect on dependent variable of participation in programs related to like protecting, revival, development and using of natural resources $(\mathrm{p}=0.000, t=0.577)$. The independent variable of the awareness of users about the importance and purposes of projects had no meaningful effect on dependent variable of participation in protecting, revival, development and using of natural resources. $(p=0.972, t=0.360)$. The independent variable of decentralization in extension management had no meaningful effect on dependent variable of people participation in protecting, revival, development and using of natural resources. $(p=0.156, t=1.48)$. The independent variable of pay attention to interests and needs of users had a meaningful effect on dependent variable of people participation in programs related to protecting, revival, development and using of natural resources with the scale of $0.1(\mathrm{p}=0.000, \mathrm{t}=5.17)$. The independent variable of user's Intention and attitude toward participation, has a meaningful effect on 
dependent variable of their association in protecting, revival, development and using of natural resources with the scale of $0.1(\mathrm{p}=0.000 \mathrm{t}=0.41)$. The independent variable of the degree of presented services too users had no meaningful effect on dependent variable of people participation in the degree of presented services too users of natural resources $(\mathrm{p}=$ $0.809, \mathrm{t}=0.246$ ). The independent variable of level of technical knowledge of users had a meaningful effect on dependent variable of participation in the degree of presented services too users of natural resources with the scale of 0.01. $(\mathrm{p}=0.000, \mathrm{t}=9.17)$. The independent variable of the current status of extension programs had a meaningful effect on the dependent variable of people participation in protecting, revival, development and using of natural resources with the scale of 0.01 . $(\mathrm{p}=0.000, \mathrm{t}=4.64)$. The variable of government planning for participation had a meaningful effect on the dependent variable of people participation in protecting, revival, development and using of natural resources with the scale of 0.05 . $(\mathrm{p}=0.952, \mathrm{t}=0.061)$. The independent variable of legal and political supports had meaningful effect on the dependent variable of people participation in protecting, revival, development and using of natural resources with the scale of $0.01 .(\mathrm{p}=0.000, \mathrm{t}=10.75)$

The independent variable of the amount of received facilities by users had meaningful effect on the dependent variable of people participation in protecting, revival, development and using of natural resources with the scale of 0.05. $(\mathrm{p}=0.04, \mathrm{t}=2.06)$.

The independent variable of the amount of irrigated and non-irrigated lands of users had no meaningful effect on the dependent variable of people participation in protecting, revival, development and using of natural resources with the scale of $0.05 .(\mathrm{p}=0.165, \mathrm{t}=1.45)$. The independent variable of organizing local associations had meaningful effect on dependent variable of people participation in protecting, revival, development and using of natural resources with the scale of 0.005. $(\mathrm{p}=0.000, \mathrm{t}=5.69)$.

Based on the research's findings for the purpose of increasing people participation in processes of protecting, revival, development and using of renewable natural resources, we suggest the followings:

- The finding of the research show that the users, with their real job and having more livestock, have more activities in protecting, revival, development and using of natural resources. Therefore, we suggest the agents of natural resources office to have more relations with people that their real job is stockbreeding and to help in development of natural resources by holding special educative classes with the purpose of transferring the instructions and policies

- The finding of the research shows that the utmost frequency of users (32.2) is between the ages of 20-30 years old. Thus, it seems that the majority of statistical society of users is young. We can attract the supports of natural resources more and more by using the age pyramid, having realistic and persuasive programs which are confirmed with their needs, step-by-step and good education

- The finding of the research show that the legalpolitic factors of government's preparation for people participation, the determination of forests and pastures boundaries with associating of people, fulfilling the government's obligations to people, supplying the requisite fuel for users by government have the highest priority on the ground of people participation in protecting, revival, development and using of natural resources with the average scale of $2.24,3.04,2.84,2.94$, respectively. Thus, for the purpose of optimizing people participation, we recommend the government to fulfill it's obligations toward people and most importantly give them the requisite fuel as soon as possible

- The study of correlation between the variables of amount of income and people participation in protecting, revival, development and using of natural resources shows that there is no meaningful relationship between these two variables. And this means that the private interest is not the only cause for having no people association. Hence, in the case of attracting popular associations and paying attention to the other aspects of lifestyle, the unity of people and executive agents, we can hope to accomplish the programs of protecting, revival, development and using of natural resources more than ever

- The finding of regression analysis show that the user's level of education is one of the effective factors on people participation in protecting, revival, development and using of natural resources. It is worth noting that the majority of statistical society involved in the survey has a very low education, just reading and writing. Therefore, it is recommended to develop the requisite plans for users to be literate, along with the collaboration of province education department and literacy crusade in particular. If these plans are accomplished, we cab be hopeful to the user's and agent's using of the latest and practical methods

- The finding of regression analysis show that the reliance of users on executives of projects related to natural resources is one of the effective factors 
on people association in protecting, revival, development and using of natural resources. Therefore, it is recommended to hold some meeting in villages, to determine exactly the principles and purposes before accomplishing any plan. Having face to face communication, Request the local leaders for help, respect to cultural norms on the behalf of executive agents can accelerate the reliability

- The finding of regression analysis show that the current state of extension program is one of the effective factors on people participation in protecting, revival, development and using of natural resources. This shows the integral role of extension in attracting people to associate in protecting, revival, development and using of natural resources. The continuation of extension role on this ground has its root in the realism group and adapting ourselves to interests and needs of users. Therefore, it is firstly better for it to be full of up-dated extension programs. On the other hand, it is better to be adapted to the level of awareness and knowledge of people. So, we must consider the aspects of fluency, simplicity and realism of extension programs

\section{REFERENCES}

Azkya, M., 2001. Sociology of Development. 2nd Edn., Kalame Publishing, ISBN: 964-6464-15-7, pp: 57-100.

Barret, O., 1991. Community participation in natural resources, management project in Asia pacific.

FAO, 2000. NGo participation. http//:www.codexalimentarius.net/web/Ngoparticipation.jsp

Fisher, R.J., 1993. Devolution and decentralization of forest management in Asia. J. For., 199: 23-45.

Hossieni, S.M., E. Faham and D. Kaivan, 2006. The study of effective factors on association of local societies in stable management of soil and water resources. Proceeding of the Conference of Planning Associated Expansion of Soil and Water, Dec. 2006, pp: 254-280.

Kaliqi, A., N. Kasemi and M.H. Taj, 2004. The study of effect of social-economical issues on the state of stockbreeders in the projects of range management. Nat. Resour. Agric. Knowl. Mag., 1: 80-94.

Kodere, H., 1995. The state cooperatives and peasants participation: The case of Peruvian agrarian reform. pp: 25-29.

Malek Mohammadi, I., 1999. Designing the sample of reforming the structure of woodman cooperatives for increasing the systematic people association in the management of North forests. For. Pasture Mag., 3: 47-53.
Mirbod, M., 2000. The role of nongovernmental organizations to promote natural resources. Master Degree Thesis, Department of Agricultural Extension and Education, Islamic Azad University, Science and Research, pp: 120-135.

Motavali, H.A., 2004. Review barriers to participation in the conservation of natural resources Semnan promotional approach. For. Rangeland J., 2: 28-45.

Mousavi, R., 2001. Management and public participation in environmental protection resources (forests) in Golestan province. Master Degree Thesis Environment, Islamic Azad University, Science and Research, pp: 101-120.

Osman, P., 2007. The study of the role and effect of Islamic councils on protecting, revival, development of natural resources of Kordestan. The dissertation of Agricultural Extension and Education Field of Study, Azad University, Science and Research Branch, pp: 48-64.

Perti, J.N., 2003. Recreation of policies and proper operations for being stable and self-assured from the agricultural point of view. Translated by Alireza Kashani. Published by the survey and Research Center of Rural Issues, The Village and Development Publications, pp: 140-168.

Pop Zan, A., 2006. The study of people and popular associations in national network based on the experience of other countries. The deputy of popularization and exploitation system of ministry of agriculture, the study and designing extension system office, the study and educativepopularizing evaluation group, pp: 38-69.

Razaki, M.R., 2000. Indigenous knowledge and modern design combined to produce land area of growing root Zagros. Agricultural Extension and Education thesis, Islamic Azad University, Science and Research, pp: 221-230.

Samari, D., 2004. The engineering of social forestation popularizing of Zagros forests. The Agricultural Extension and Education Dissertation. Azad University, Science and Research Branch, pp: 98-114.

Shaeri, A.M., 1998. Designing participating-extension model. Admitting the project of exiting the livestock from the forests of the Caspian Sea's territory. The Agricultural Extension and Education Dissertation, Azad University, Science and Research Branch, pp: 85-102.

Shariaati, M. and B. Reza, 2004. The effective factors on woodsmen and rural people in protecting the north and west forests of Iran. For. Pasture Period., 2: 38-49. 